\title{
CEREBRAL ASPERGILLOSIS DUE TO Aspergillus fumigatus IN AIDS PATIENT: FIRST CULTURE-PROVEN CASE REPORTED IN BRAZIL
}

José E. VIDAL(1), Rafi F. DAUAR(1), Marcia S.C. MELHEM(2), Walderez SZESZS(2), Sandra R.B.S. PUKINSKAS(1), João F.G.S. COELHO(1), Diogo L.M. LINS(1), Silvia F. COSTA(3), Augusto C. PENALVA DE OLIVEIRA(1) \& Carlos da Silva LACAZ

\begin{abstract}
SUMMARY
Cerebral aspergillosis is a rare cause of brain expansive lesion in AIDS patients. We report the first culture-proven case of brain abscess due to Aspergillus fumigatus in a Brazilian AIDS patient. The patient, a 26 year-old male with human immunodeficiency virus (HIV) infection and history of pulmonary tuberculosis and cerebral toxoplasmosis, had fever, cough, dyspnea, and two episodes of seizures. The brain computerized tomography (CT) showed a bi-parietal and parasagittal hypodense lesion with peripheral enhancement, and significant mass effect. There was started anti-Toxoplasma treatment. Three weeks later, the patient presented mental confusion, and a new brain CT evidenced increase in the lesion. He underwent brain biopsy, draining $10 \mathrm{~mL}$ of purulent material. The direct mycological examination revealed septated and hyaline hyphae. There was started amphotericin B deoxycholate. The culture of the material demonstrated presence of the Aspergillus fumigatus. The following two months, the patient was submitted to three surgeries, with insertion of drainage catheter and administration of amphotericin B intralesional. Three months after hospital admission, his neurological condition suffered discrete changes. However, he died due to intrahospital pneumonia. Brain abscess caused by Aspergillus fumigatus must be considered in the differential diagnosis of the brain expansive lesions in AIDS patients in Brazil.
\end{abstract}

KEYWORDS: Cerebral aspergillosis; Focal brain lesions; Invasive aspergillosis; Aspergillus fumigatus; Acquired immunodeficiency syndrome; Brazil.

\section{INTRODUCTION}

The invasive aspergillosis has emerged as an increasing cause of morbidity and mortality in immunocompromised patients, especially these with hematologic cancer (leukemia or lymphoma) and bone marrow transplant ${ }^{16,20}$.

The most frequent clinical form is invasive pulmonary aspergillosis $(80-90 \%)^{17}$, which could be disseminated, compromising the central nervous system (CNS) in up to $10-25 \%$ of the $\operatorname{cases}^{8,11,17,24}$. The neurological manifestations are several, including meningitis, encephalitis, brain abscess, and/or cerebral infarct. In neurohistopathological studies, the main manifestations are hemorrhagic infarcts and abscesses ${ }^{23,31}$.

The overall case-fatality rate of invasive aspergillosis is approximately $60 \%$ and depend on several factors, including host group, site of disease, and delayed therapy ${ }^{7,14,15}$. The case-fatality rate is higher for bone marrow transplant $(\sim 90 \%)$ and for patients with central nervous system or disseminated aspergillosis $(>95 \%)^{14}$.
The incidence of invasive aspergillosis in HIV/AIDS patients varies within $0-12 \%^{8}$.

HIV/AIDS constitutes $<5 \%$ of all underlying conditions among cases with invasive aspergillosis and the third underlying condition with higher aspergillosis case-fatality rate $(\sim 80 \%)$, after bone marrow transplant and liver transplant ${ }^{7,14,25}$.

Cerebral aspergillosis is a rare cause of intracranial mass lesion in AIDS patients. In this study, we report a fatal case of brain abscess caused by Aspergillus fumigatus in AIDS patient and review of the literature.

\section{CASE REPORT}

A 26 year-old homosexual male, with HIV infection since 1996, was admitted in December 1999 at the Instituto de Infectologia Emilio Ribas, complaining of 10 days with fever, productive cough and dyspnea, and two episodes of generalized tonic-clonic seizures within the last 24 hours. He referred history of pulmonary tuberculosis and cerebral toxoplasmosis with neurologic sequelae characterized by right

(1) Instituto de Infectologia Emílio Ribas, São Paulo, SP, Brazil.

(2) Instituto Adolfo Lutz, São Paulo, SP, Brazil.

(3) Hospital das Clínicas, FMUSP, São Paulo, SP, Brazil.

In memorian

Correspondence to: Dr. José E. Vidal, Rua Capote Valente 668, Apto 78, 01249-000 São Paulo, SP, Brasil. E-mail: jbermudez@emilioribas.sp.gov.br 


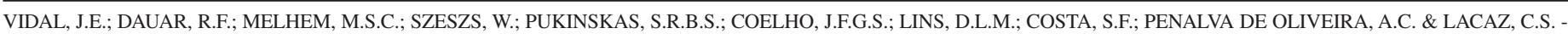
Cerebral aspergillosis due to Aspergillus fumigatus in AIDS patient: first culture-proven case reported in Brazil. Rev. Inst. Med. trop. S. Paulo, 47(3): 161-165, 2005.

hemiparesis. He reported irregular use of zidovudine, lamivudine, indinavir, dapsone, pyrimethamine, and folinic acid. Physical examination disclosed significant weigh loss, paleness, oral thrush, fever $\left(38.2^{\circ} \mathrm{C}\right)$, and tachydyspnea. There was also observed non-painful hepatomegaly and crepitations in the right hemithorax base. The neurological examination evidenced mental confusion and incomplete, disproportional, and spastic hemiparesis in the right hemibody. The rest of the examination was unremarkable. Laboratorial tests detected moderate anemia (hemoglobin $=10.1 \mathrm{~g} / \mathrm{dL})$, leukocytosis $(17,800$ cells/ $\mathrm{mm}^{3}$ ) with shift to left (13\% of bands), and lymphopenia ( $\left.8 \%\right)$. The tests on IgG antibodies against Toxoplasma, Herpes simplex, and Cytomegalovirus were positive. Two hemocultures showed growing of Klebsiella pneumoniae. The $\mathrm{CD}^{+}$lymphocytes count was 8 cells $/ \mathrm{mm}^{3}$. The chest X-ray evidenced basal lobar consolidation in the right hemithorax. Brain CT indicated two focal lesions. Only the larger one present with ring-enhancing and mass effect (Fig. 1). Lumbar tap showed normal cerebrospinal fluid (CSF), with three leukocytes $/ \mathrm{mm}^{3}$, $32 \mathrm{mg} / \mathrm{dL}$ of glucose, $38 \mathrm{mg} / \mathrm{dL}$ of proteins, and no microorganism in direct tests and cultures for bacteria, fungus, and mycobacterium. Besides the supporting measures, ceftriaxone two g/day, fluconazole $100 \mathrm{mg} /$ day, sulfadiazine $1.5 \mathrm{~g}$ FID, pyrimethamine $25 \mathrm{mg} /$ day, fonilic acid $15 \mathrm{mg} /$ day, dexamethasone four $\mathrm{mg}$ FID, and phenytoin $100 \mathrm{mg}$ TID were initiated. Three weeks later, we evidenced important improvement on his respiratory condition, but the patient persisted with fever, seizures, and mental confusion. A new CT showed enlargement of the brain expansive lesion. He underwent trepanation, draining $10 \mathrm{~mL}$ of purulent material. The direct examination demonstrated presence of septate hyalines hyphae. There was started amphotericin B deoxycholate $40 \mathrm{mg} / \mathrm{day}$. Three days later, the culture was indicative of Aspergillus spp., which was later confirmed as Aspergillus fumigatus. The following two months, the patient was submitted to three other surgeries, with insertion of drainage catheter with reservoir, and administration of amphotericin B intralesional. The direct mycological assays of the material samples drained remained positive; however, the hemocultures for fungus were persistently negative. After receiving a total dosage of $2.5 \mathrm{~g}$ of amphotericin $\mathrm{B}$ deoxycholate, and due to the occurrence of acute renal insufficiency (creatinine $>2.5 \mathrm{mg} / \mathrm{dL}$ ), the medication was changed to $400 \mathrm{mg} / \mathrm{day}$ of itraconazole (PO). At this time, there was no available lipidassociated amphotericin B preparation in our hospital. The neurological condition suffered discrete changes, showing fever and mental confusion, and the polymorphonuclear leukocytes count was normal. Three months after hospital admission, the patient died due to intrahospitalar pneumonia. The necropsy was not carried out due to lack of family consent.

\section{MYCOLOGIC DIAGNOSIS}

Direct examination of cerebral tissue with $20 \% \mathrm{KOH}$ showed the presence of septate hyphae (Fig. 2). Giemsa stain showed the same structures. Also, purulent material was cultured on Sabouraud dextrose agar and brain heart infusion agar, adding chloramphenicol in both, incubated at $30{ }^{\circ} \mathrm{C}$. After 72 hours, were observed white colonies with cottoned texture, which turned into dark gray-greenish tonality due to the formation of spores. The backside of the colonies showed a white coloration, without diffusible pigment. Slide micro-culture revealed branched septate hyaline hyphae with conidiophore with smooth wall, constituted of hemispheric vesicles with greenish color in the upper part. A single series of phialides, giving origin to rounded and rarely rough conidia, disposed in long and parallel chain, completed the characteristics which allowed us to identify the fungus as Aspergillus fumigatus $^{13}$ (Fig. 3).

The sensibility profile in vitro was carried out, according to the protocol for filamentous fungi recommended by the National Committee for Clinical Laboratory Standards (NCCLS) M38-A ${ }^{18}$. The antifungal analyzed were amphotericin B, itraconazole, and fluconazole, applying the micro-dilution method in RPMI 1640 liquid, having Candida krusei (ATCC ${ }^{\circledR}$ 6258) and Candida parapsilosis (ATCC ${ }^{\circledR} 22019$ ) as standard species. The values of the minimal inhibitory concentration (MIC) were $1 \mu \mathrm{g} / \mathrm{mL}, 1 \mu \mathrm{L} / \mathrm{mL}$, and $\geq 32 \mu \mathrm{L} /$ $\mathrm{mL}$ for amphotericin $\mathrm{B}$, itraconazole, and fluconazole, respectively.

\section{DISCUSSION}

This report constitutes, to our knowledge, the first culture-proven case of brain abscess caused by Aspergillus fumigatus in a Brazilian AIDS patient.

The clinical presentation of the invasive aspergillosis depends on clinical condition of the population studied. In general, patients with severe levels of immunosuppression (i.e. allogeneic bone marrow transplant recipients) show few symptoms initially and evolve fast (acute invasive pulmonary aspergillosis). Conversely, less immunocompromised patients (i.e. AIDS patients), show usually a more indolent, symptomatic manifestation that progress slowly (i.e. chronic invasive pulmonary aspergillosis).

There are few reports on cerebral aspergillosis in patients with AIDS. A recent literature review identified 33 cases only, including those with definitive or probable diagnosis ${ }^{17}$.

Cerebral aspergillosis would come from two different mechanisms: (i) hematogenic dissemination; or (ii) direct extension of an area anatomically adjacent to the brain (i.e. sinuses, hear, orbit). In $25 \%$ of patients with AIDS, in the same way as it happened with the current report, the cerebral aspergillosis could be the only clinical manifestation of the disease, complicating the diagnosis ${ }^{17}$.

The main conditions associated to the development of cerebral aspergillosis in patients with AIDS are neutropenia and the use of corticosteroids. However, these conditions could not be present ${ }^{17}$.

The CSF findings on patients with cerebral aspergillosis and AIDS are unspecified ${ }^{16}$ and neuroradiological alterations are frequent $(\sim 85 \%)$, especially showing single lesions $(\sim 60 \%)^{17}$.

The cerebral aspergillosis radiological findings in immunocompromised patients include: (i) hypodense cortical and subcortical lesions in CT or hyperintense in T2-weighted MRI, corresponding to cerebral infartcs; (ii) nodular or ring-enhancing lesions; and (iii) meningeal enhancement adjacent to the paranasal sinuses or enhancement of the optical nerve and orbit fat ${ }^{2}$. These presentations seem to be related to the level of immunosuppression and to the stage of the fungal infection ${ }^{6}$. In patients with severe immunosuppression (i.e. marrow bone transplant recipients), brain 


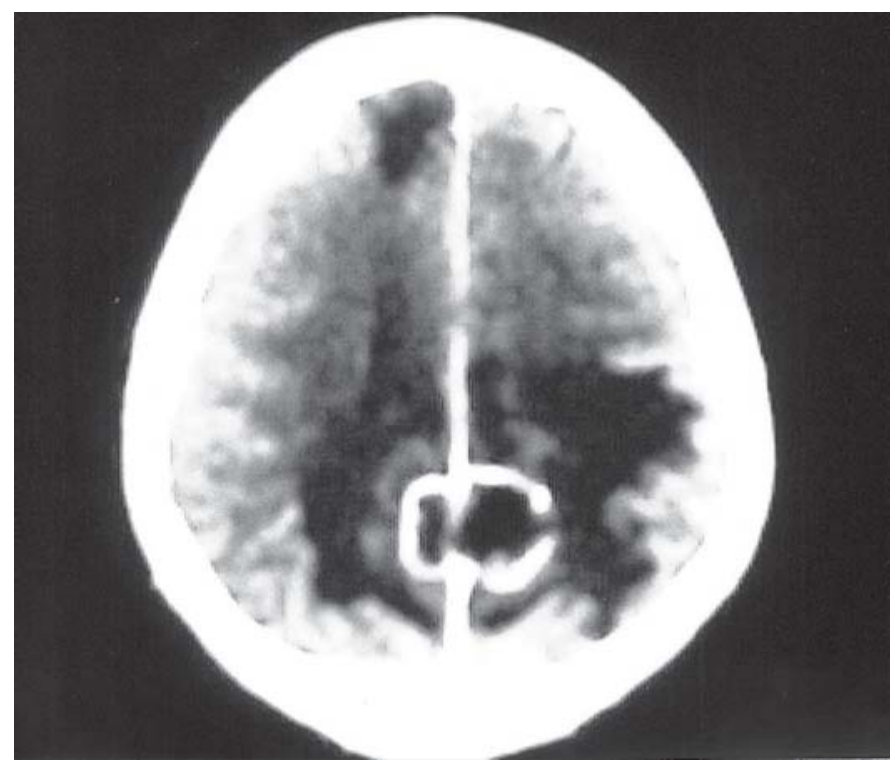

Fig. 1 - Brain computerized tomography with contrast, showing an extra-axial, bi-parietal, and parasagittal hypodense lesion with peripheral enhancement and significant perilesional edema. Another hypodense lesion, without enhancement or expansive effect in the right frontal region can also be observed.

lesions, generally, are consistent with acute infarct resulting in a rapid fatal outcome. In patients with less severe immunosuppression (i.e. AIDS patients), generally brain lesions show ring or nodular enhancement consistent with granulomas or abscesses ${ }^{6,19}$. Aside from these considerations, as it happened in the current report, the radiological findings could be varied. Some authors point out that patients with expansive brain lesions show improved prognostics ${ }^{19}$. Nevertheless, the general consensus is that the lethality of all forms of cerebral aspergillosis, regardless the subjacent disease and radiological pattern, varies within $90-100 \% \%^{6,14,17,23,24}$.

Recommendations for evaluation and management of expansive brain lesions in AIDS patients has been reported elsewhere ${ }^{22}$. Patients with positive serology for Toxoplasma gondii must undergo toxoplasmosis empirical treatment. After 10-14 days, the persistence or worsening of either clinical symptomatology or the mass lesion observed on radiographic imaging indicates the performance of brain biopsy. In some circumstances, the surgical approach must be carried out at an early stage. Emphasis should be placed to the following situations: concomitance of negative toxoplasmosis serology and a single brain lesion ${ }^{22}$, large lesions with mass effect threatening herniation $^{22}$, or high level of suspicion of some alternative diagnostics to cerebral toxoplasmosis ${ }^{3,29}$. Patients with suspicion of invasive aspergillosis and presence of focal brain lesions in radiographic imaging must be intensively evaluated. This approach could contribute to a reduction on the number of post-mortem diagnostics, reported in 50\% of the cases $^{17}$.

In recent years, the availability of molecular methods, applying the polymerase chain reaction (PCR) in CSF, has been characterized as "minimally invasive" diagnostic approaches on expansive brain lesions in AIDS patients. This strategy helped to decrease the number

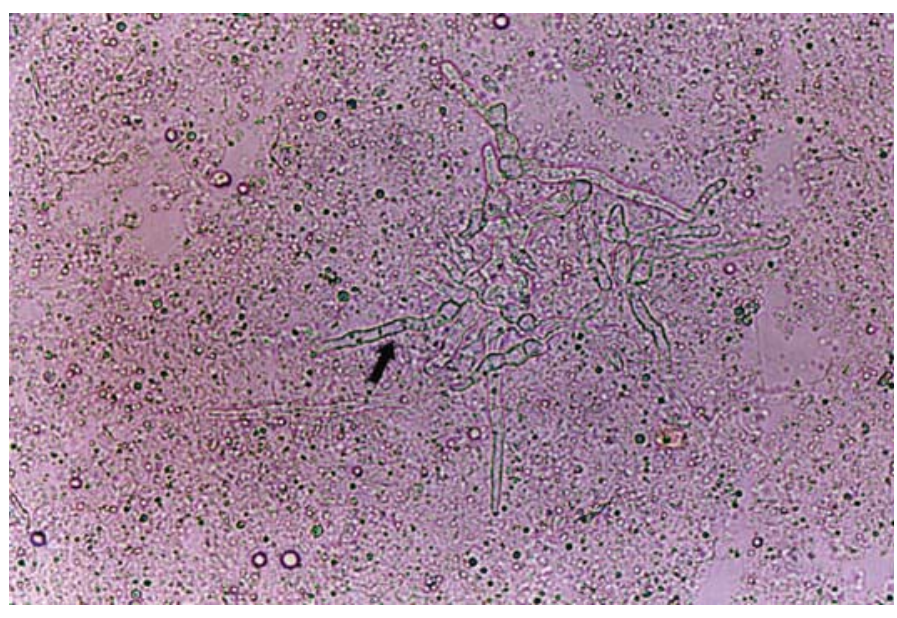

Fig. 2 - Direct mycological examination of the brain abscess material showing septate hyaline hyphae (arrow) (X 400).

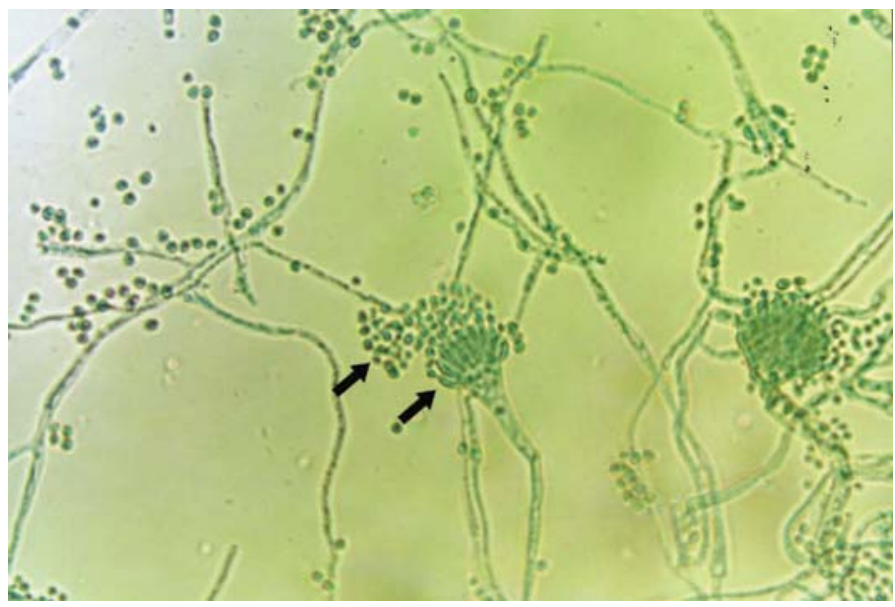

Fig. 3 - Aspergillus fumigatus microscopic characteristics. A single series of phialides (right arrow) can be observed, giving origin to the rounded conidia disposed in long and parallel chains (left arrow) (Lacto phenol cotton blue X400).

of brain biopsies, increasing the number of in vivo diagnoses ${ }^{1}$. Besides, imaging techniques, such as thallium-201 single emission computed tomography (SPECT), positron emission tomography (PET), and spectroscopy could help in some cases. As for the cerebral aspergillosis, there is little information available on these techniques ${ }^{12,27}$.

The treatment of cerebral aspergillosis is difficult and complex. The approaches include systemic antifungal and surgical treatment of the abscesses (aspiration or abscess resection) ${ }^{23,24}$.

The main challenge for the majority of the available antifungal, such as amphotericin B deoxycholate or liposomal formulations, itraconazole, and caspofungin, is its limited penetration into the bloodbrain-barrier and/or brain tissue ${ }^{23,24}$.

The most reported cerebral aspergillosis cases with survival were not associated to AIDS and received neurosurgical treatment and several antifungal schemes (amphotericin B deoxycholate, with or without 5- 


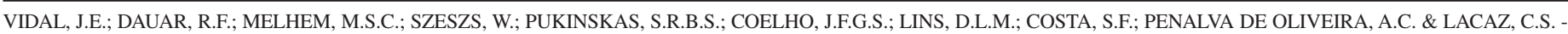
Cerebral aspergillosis due to Aspergillus fumigatus in AIDS patient: first culture-proven case reported in Brazil. Rev. Inst. Med. trop. S. Paulo, 47(3): 161-165, 2005.

fluocytosine; conventional amphotericin in lipidic emulsion, liposomal amphotericin, ABLC, or itraconazole $)^{4,23}$. Some studies in patients without AIDS suggest that the neurosurgical approach improves the outcome $^{4,26}$. However, the true value of surgical interventions must be systematically assessed.

Treatment results of CNS aspergillosis in AIDS patients have been very disappointing. A review reported inefficacy of any antifungal drugs associated or not to neurosurgery in $100 \%$ of $22 \mathrm{cases}^{17}$. The antifungals included amphotericin B deoxycholate, amphotericin B lipidic complex, or itraconazole. In our case report, the systemic and intralesional use of the amphotericin B deoxycholate and the repeated surgical drainages did not help to avoid the lethal evolution.

There is little information available on the clinical use of the antifungal susceptibility tests for the filamentous fungi, including the Aspergillus species, despite the recommended reference methods ${ }^{18}$. Preliminary information indicates that the MIC $>2 \mu \mathrm{L} / \mathrm{mL}$ for the amphotericin and the MIC $>8 \mu \mathrm{L} / \mathrm{mL}$ for the itraconazole are associated to the clinical resistance ${ }^{18}$. However, the filamentous fungi, usually, are not susceptible to the fluconazole, showing MICs $>64 \mu \mathrm{L} / \mathrm{mL}^{18}$. Considering those breakpoints, the A. fumigatus sample isolated from the case showed in vitro sensibility to the administrated antifungal (amphotericin B and itraconazole). However, there were no serum levels of itraconazol available. For this reason, we did not rule out any problem related to absorption of this azole. It is presumed that factors related to the condition of our patient, besides the antifungal susceptibility could be associated to his outcome. AIDS patients differ from the other major risk groups in that their underlying disease is progressive and incurable, complicating any therapeutic approach ${ }^{7}$.

In addition, reference methods on antifungal susceptibility tests for filamentous fungi indicate that there are not enough information available that could demonstrate the correlation between MIC and clinical outcome with the use of new imidazolic ${ }^{18}$, including voriconazole.

Voriconazole is a newly approved imidazolic for the treatment of invasive aspergillosis that demonstrated higher activity compared to the amphotericin $\mathrm{B}^{10}$. Different to other antifungal, some studies point out that this drug shows adequate penetration into the CSF and in the brain tissue ${ }^{23,24}$. Despite the inexistence of case reports on cerebral aspergillosis and AIDS treated with voriconazole available, there are evidences suggesting its potential use in this population. Six of eight case reports (seven immunocompromised and one immunocompetent) revealed a remission of cerebral aspergillosis with the use of voriconazole, after the unsuccessful use of several antifungal ${ }^{5,15,23,28}$. Furthermore, data from clinical and compassionate use programs support the use of voriconazole, reported a complete or partial response

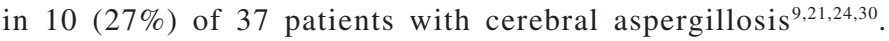
Additionally, a recent retrospective study, which evaluated 81 patients with definitive or probable cerebral aspergillosis treated with voriconazole, demonstrated complete or partial response and survival on $35 \%$ and $31 \%$ of cases, respectively ${ }^{26}$. Currently, some authors suggest the use of voriconazole as choice treatment for cerebral aspergillosis ${ }^{5,24}$. However, further studies are necessary to determine more precisely the role of voriconazole in this setting.
In conclusion, brain abscess caused by Aspergillus fumigatus must be considered in the differential diagnosis of the brain expansive lesions in AIDS patients. High level of clinical and radiological suspicion could lead to early diagnostic and treatment approaches of this lethal disease.

\section{RESUMEN}

\section{Aspergilosis cerebral causada por Aspergillus fumigatus en paciente con SIDA: primer reporte de caso demostrado por cultivo en Brasil}

La aspergilosis cerebral es una causa rara de lesión expansiva cerebral en pacientes con SIDA. Presentamos el primer reporte de un absceso cerebral causado por Aspergillus fumigatus en un paciente brasileño con SIDA. El paciente, de 26 años de edad, presentaba antecedentes de infección por el virus de la inmunodeficiencia humana (VIH), tuberculosis pulmonar y toxoplasmosis cerebral. Manifestó fiebre, tos, disnea y dos episódios de convulsiones. La tomografía computadorizada (TC) demostró una lesión hipodensa parasagital y bi-parietal con realce periférico e importante efecto de masa. Se inició tratamiento anti-Toxoplasma. Tres semanas después, el paciente evidenció confusión mental y una nueva TC de cráneo mostró aumento de la lesión. Se realizó biopsia cerebral con drenaje de $10 \mathrm{~mL}$ de material purulento. El examen micológico directo reveló hifas hialinas septadas. Se inició anfotericina B deoxicolato. La cultura del material demostró presencia de Aspergillus fumigatus. En los siguientes dos meses el paciente fue sometido a otras tres cirugías, insertándose un catéter de drenaje y administrándose anfotericina B intralesional. Tres meses después de la admisión hospitalaria, la condición neurológica del paciente sufrió discretos cambios. Sin embargo, falleció debido a neumonia intrahospitalaria. Aunque muy raros, los abscesos cerebrales causados por Aspergillus fumigatus deben ser considerados en el diagnóstico diferencial de las lesiones expansivas cerebrales en pacientes con SIDA.

\section{ACKNOWLEDGEMENTS}

This study was supported, in part, by the Centro de Estudos Emílio Ribas, São Paulo, Brasil.

\section{REFERENCES}

1. ANTINORI, A.; AMMASSARI, A.; DE LUCA, A. et al. - Diagnosis of AIDS-related focal brain lesions: a decision-making analysis based on clinical and neuroradiologic characteristics combined with polymerase chain reaction assays in CSF. Neurology, 48: 687-694, 1997

2. ASHDOWN, B.C.; TIEN, R.D. \& FELSBERG, G.J. - Aspergillosis of the brain and paranasal sinuses in immunocompromised patients: CT and MR imaging findings. Amer. J. Roentgenol., 162: 155-159, 1994.

3. BASSIL, H.F. \& WILLIAM, D.C. - Cytomegalovirus encephalitis in an HIV positive patient presenting with a cerebral mass lesion. AIDS Patient Care and STDS, 11: 319-321, 1997.

4. COLEMAN, J.M.; HOGG, G.G.; ROSENFELD, J.V. \& WATERS, K.D. - Invasive central nervous system aspergillosis: cure with liposomal amphotericin B, itraconazole, and radical surgery: case report and review of the literature. Neurosurgery, 36: 858863,1995 . 


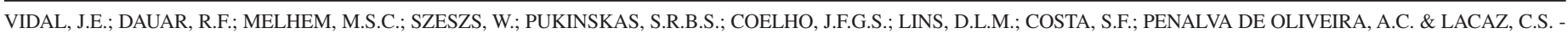
Cerebral aspergillosis due to Aspergillus fumigatus in AIDS patient: first culture-proven case reported in Brazil. Rev. Inst. Med. trop. S. Paulo, 47(3): 161-165, 2005.

5. DE LASTOURS, V.; LEFORT, A.; ZAPPA, M. et al. - Two cases of cerebral aspergillosis successfully treated with voriconazole. Europ. J. clin. Microbiol. infect. Dis., 22: 297-299, 2003.

6. DELONE, D.R.; GOLDSTEIN, R.A.; PETERMANN, G. et al. - Disseminated aspergillosis involving the brain: distribution and imaging characteristics. Amer. J. Neuroradiol., 20: 1597-1604, 1999.

7. DENNING, D.W. - Therapeutic outcome in invasive aspergillosis. Clin. infect. Dis., 23: 608-615, 1996.

8. DENNING, D.W. - Aspergillus species. In: MANDELL, G.L.; BENNETT, J.E. \& DOLIN, R., ed. Mandell, Douglas, and Bennett's principles and practice of infectious diseases. 5. ed. Philadelphia, Churchill Livingstone, 2000. p. 2674-2684.

9. DENNING, D.W.; RIBAUD, P.; MILPIED, N. et al. - Efficacy and safety of voriconazole in the treatment of acute invasive aspergillosis. Clin. infect. Dis., 34: 563-571, 2002.

10. HERBRECHT, R.; DENNING, D.W.; PATTERSON, T.F. et al. - Voriconazole versus amphotericin B for primary therapy of invasive aspergillosis. New Engl. J. Med., 347: 408-415, 2002.

11. KAPLAN, K. - Brain abscess. Med. Clin. N. Amer., 69: 345-360, 1985.

12. KOMATSU, H.; FUJISAWA, T.; INUI, A. et al. - Molecular diagnosis of cerebral aspergillosis by sequence analysis with panfungal polymerase chain reaction. $\mathbf{J}$. pediat. Hemat. Oncol., 26: 40-44, 2004.

13. LACAZ, C.S.; PORTO, E.; HEINS-VACCARI, E.M. \& MELO, N.T. - Aspergillus spp. (Micheli \& Link 1809). In: LACAZ, C.S.; PORTO, E.; HEINS-VACCARI, E.M. \& MELO, N.T., ed. Guia para identificação: fungos, actinomicetos e algas de interesse médico. São Paulo, Sarvier, 1998. p. 177-186.

14. LIN, S.J.; SCHRANZ, J. \& TEUTSCH, S.M. - Aspergillosis case fatality rate: systematic review of the literature. Clin. infect. Dis., 32: 358-366, 2001.

15. MARBELlO, L.; NOSARI, A.; CARRAFIELLO, G. et al. - Successful treatment with voriconazole of cerebral aspergillosis in an hematologic patient. Haematologica, 88: ECRO5, 2003

16. McNEIL, M.M.; NASH, S.L.; HAJJEH, R.A. et al. - Trends in mortality due to invasive mycotic diseases in the United States, 1980-1997. Clin. infect. Dis., 33: 641-647, 2001.

17. MYLONAKIS, E.; PALIOU, M.; SAX, P.E. et al. - Central nervous system aspergillosis in patients with human immunodeficiency virus infection. Report of 6 cases and review. Medicine, 79: 269-280, 2000.

18. NCCLS - Reference method for broth dilution antifungal susceptibility testing of filamentous fungi. Approved Standard. Wayne, NCCLS, 2002. (NCCLS document M38-A).
19. OKAFUGI, T.O.; YABUUCHI, H.; NAGATOSHI, Y.; HATTANDA, Y. \& FUKUYA, T. $\mathrm{CT}$ and MR findings of brain aspergillosis. Comput. Med. Imaging Graph., 27: 489-492, 2003.

20. PATTERSON, T.F.; KIRKPATRICK, W.R.; WHITE, M. et al. - Invasive aspergillosis. Disease spectrum, treatment, and outcomes. I3 Aspergillosis Study Group. Medicine, 79: $250-260,2000$.

21. PERFECT, J.R.; MARR, K.A.; WALSH, T.J. et al. - Voriconazole treatment for lesscommon, emerging, or refratory fungal infections. Clin. infect. Dis., 36: 1122-1131, 2003.

22. QUALITY STANDARDS SUBCOMMITTEE OF THE AMERICAN ACADEMY OF NEUROLOGY - Evaluation and management of intracranial mass lesions in AIDS. Neurology, 50: 21-26, 1998 .

23. SCHWARTZ, S. \& THIEL, E. - CNS-aspergillosis: are there new treatment options? Mycoses, 46(suppl. 2): 8-14, 2003.

24. SCHWARTZ, S. \& THIEL, E. - Update on the treatment of cerebral aspergillosis. Ann. Hemat., 83(suppl. 1): S42-S44, 2004.

25. SINGH, N.; AVERY, R.K.; MUÑOZ, P. et al. - Trends in risk profiles for and mortality associated with invasive aspergillosis among liver transplant recipients. Clin. infect. Dis., 36: 46-52, 2003.

26. TROKE, P.F.; SCHWARTZ, S.; RUHNKE, M. et al. - Voriconazole (VRC) therapy (Rx) in 86 patients (pts) with CNS aspergillosis (CNSA): a retrospective analysis. In: INTERSCIENCE CONFERENCE ON ANTIMICROBIAL AGENTS AND CHEMOTHERAPY, 43., Chicago, 2003. Abstracts. p. 476, M-1755.

27. VENKATESH, S.K.; GUPTA, R.K.; PAL, L.; HUSAIN, N. \& HUSAIN, M. Spectroscopic increase in choline signal is a nonspecific marker for differentiation of infective/inflammatory from neoplastic lesions of the brain. J. Magn. reson. Imaging, 14: 8-15, 2001.

28. VERWEIJ, P.E.; BRINKMAN, K.; KREMER, H.P.; KULLBERG, B.J. \& MEIS, J.F. Aspergillus meningitis: diagnosis by non-culture-based microbiological methods and management. J. clin. Microbiol., 37: 1186-1189, 1999.

29. VIDAL, J.E.; CIMERMAN, S.; SILVA, P.R. et al. - Tuberculous brain abscess in a patient with AIDS: case report and literature review. Rev. Inst. Med. trop. S. Paulo., 45: 111-114, 2003.

30. WALSH, T.J.; LUTSAR, I.; DRISCOLL, T. et al. - Voriconazole in the treatment of aspergillosis, scedosporiosis and other invasive fungal infections in children. Pediat. infect. Dis. J., 21: 240-248, 2002.

31. YAMADA, K.; ZOARSKY, G.H..; ROTHMAN, M.I. et al. - An intracranial aspergilloma with low signal on T2-weighted images corresponding to iron accumulation. Neuroradiology, 43: 559-561, 2001.

Received: 23 November 2004

Accepted: 4 January 2005 